\title{
畺空管玻璃研 究簡報
}

\section{中國科學院治金陶瓷研究所}

真空管玻唡是指用來做無綫電貪空管或其他 類型的電子管玻唡鼓和內部玻瑞零件的玻琌。這 種玻璃在性能上主要有下列幾個要求:

1. 具有適賞的膨脹係數, 能與鵭絲或一種鐵 嵲銛合金焊合，

2. 在較高的使用温度下, 仍能保持足够的體 電阻率,

3. 有較好的抗熱性能,

4. 透明度不太美, 能發散輻射熱。

國內過去製造無綫電䢐空管或其他 類 型的 電子管, 大都探用美货, 如柯隬寧公司出品的 G $702 \mathrm{P}$ 和 772 “Nonex”玻琌。

本所根據工業需要, 在解放後進行了 G 702 $P$ “Nonex”玻琌的仿䌘工作。目前已初步完成。 現將此項工作介紹如下:

\section{一 仿製根㨜}

所謂 G $702 \mathrm{P}$ “Nonex" 玻琌是一種含 $\mathrm{PbO}$ 同時又含 $\mathrm{B}_{2} \mathrm{O}_{3}$ 的所謂矹鉛質玻琌。我們對遭種 玻瑜的仿製，是根據下列凩方西的資料進行的:

1. 前中央研究院工程研究所 (即本所前身) 對一 種美貨员空管玻款的化學成份分析, 2. 交缺上所 記載的 G 702 P “Nonex”玻璃的化學成份, 3. 柯 “爾蜜公司出品目錄上所載的 G 702 P “Nonex" 玻豍的一些物性數據。

\section{二 工作總結簡述}

我們試驗結果, 最後獲得兩種性能比較好的 玻琌。

$\begin{array}{cl}\text { 所用原料是: } & \\ \mathrm{SiO}_{2}: & \text { 石英粉 } \\ \mathrm{B}_{2} \mathrm{O}_{3}: & \text { 矹酸和硼砂 } \\ \mathrm{PbO}: & \text { 紅丹 } \\ \mathrm{Na}_{2} \mathrm{O}: & \text { 純碱和唧砂 } \\ \mathrm{K}_{2} \mathrm{O}: & \text { 碳酸鉀 }\end{array}$

此外，篇了揢製的需要，在配方中探用火确 （硝酸鉀）和智利硝（硝酸釗）作篇氧化劑; 探用 白䂤 (三氧化二䂰) 作篇澄清劑。

\section{料方成份:}

\begin{tabular}{|c|c|c|c|c|}
\hline 原 & 料 名 & 程 & 005 號 & 008 (2) 號 \\
\hline 石 & 英 & 粉 & 100.00 & 100.00 \\
\hline 硼 & & 酸 & 40.21 & 22.38 \\
\hline 矹 & & 砂 & - - & 27.40 \\
\hline 紅 & & 丹 & 8.42 & 8.41 \\
\hline 铩 & & 打 & 5.39 & - \\
\hline 谳 & 酸 & 䤠 & 2.82 & - \\
\hline 智 & 利 & 确 & - & 0.90 \\
\hline 火 & & 确 & 2.66 & 2.95 \\
\hline 白 & & 哳 & 1.00 & 1.00 \\
\hline 澋 & & 料 & 48.15 & 48.91 \\
\hline 合 & & 計 & 208.65 & 211.95 \\
\hline
\end{tabular}

上列料方中所列數字都是按所用原料的純 度作晟 $100 \%$ 純粹計算。

我們在試驗中所用的原料，全部探用市售的 普通筡玻瑞原料。對於這種玻璃的仿製，我們試 驗結果，圶部原料中除石英粉不要探用含 $\mathrm{Al}_{2} \mathrm{O}_{3}$ 太高者和一般原料的含鐵量應滥可能 低一點之 外，祇要牠們的純度能够澾到普通製玻璃用的原 料的標集，並没有其他特殊的要求。

不過由於這種玻琌在聺製過程中很不易均匀 一致, 所以，我們把上述原料在配合之前，作了 過箱的處理, 使它們在顆柆大小上適合聺製要 求。

對於造種玻瑞的仿製，熔製手續必須比較嚴 密控制, 否則, 會使玻璃成品中引起碇重的條 
敉、氣泡及砂保等等缺陷。在全部粉料配合之 後, 須反覆節拔。碎料則等全部粉料排和之後, 再行加大。熔炶最高温度的要求是: 在塔爐內部 要求 $1480^{\circ} \mathrm{C}$ (用鉑一鉑 $10 \%$ 銠合金熱電偶測 量), 在此鍋內部要求 $1430^{\circ} \mathrm{C}$ (用光學测温儀測 量)。由於目前國産沚堝對這種玻璃的抗蝕性 較 美, 因此我們探用了下列兩項圤堝處理的辦法來 淮行補救:（1）空计堝燒結，就是把圳堝在接觸 玻璃之前, 在玻璃熔爐內用 $1450^{\circ}-1480^{\circ} \mathrm{C}$ 高温 燒結6-8 小時, 使其充分瓷化。（2）橎堝, 就是 - 把一部分配方中的碎料, 不推入粉料, 在粉料之 前, 先行加入堝內, 並塗嬏在诗堝內壁和底部, 以減少粉料對坦佩的侵玲。

加料温度, 在熔煏內部維持 $1450^{\circ} \mathrm{C}$, 此城內 部, 在第一次加料前達到 $1400^{\circ} \mathrm{C}$ 。一般玻琌熔 製過程大致分篇熔化、澄清和冷却三個階段，對 於這種玻璃的熔製, 我們的經驗, 冷却階段是一 個重點。就是當玻琌在澄清之後, 不售它立刻冷 却到操作温度, 而謢它停留在 $1400^{\circ} \mathrm{C}$ (佩內温度) 左右一個相當時間，利用融揢玻璃在圤城中的對 流而引起自然覮拌作用, 使玻唡均匀混和。用這 方法可以避免玻璃中產生條紋的缺陷。我們最後 探用的聺製程序如下:

\begin{tabular}{|c|c|c|c|}
\hline 撘製過程 & 哺內温度 & 堝內温度 & 時 \\
\hline 熔 化 & $1480^{\circ} \mathrm{C}$ & $\begin{array}{l}\text { 料完全愹 } \\
\text { 化後到達 } \\
1430^{\circ} \mathrm{C}\end{array}$ & 8 小時左右 \\
\hline 澄 清 & $1480^{\circ} \mathrm{C}$ & $\begin{array}{l}\text { 保 持 } \\
1430^{\circ} \mathrm{C}\end{array}$ & 7 小㭙左右 \\
\hline 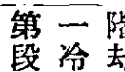 & $1450^{\circ} \mathrm{C}$ & $1400^{\circ}$ & 8 小時左右 \\
\hline 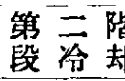 & $\begin{array}{l}1450^{\circ}- \\
1350^{\circ} \mathrm{C}\end{array}$ & $\begin{array}{l}1400^{\circ}= \\
1300^{\circ} \mathrm{C}\end{array}$ & $2-3$ 小時 \\
\hline
\end{tabular}

玻璃操作温度, 以在 $1300^{\circ} \mathrm{C}-1350^{\circ} \mathrm{C}$ 左右 䉆最適宜。若低於 $1300^{\circ} \mathrm{C}$, 便會開始發生析晶 現象。此外, 在操作進行中, 除開始時括除一次 玻唡液湎浮渣之外, 以後隨時取料, 隨時須注意 玻琌液面情况進行括料, 否則玻琌中會引起砂㞕 的缺陷。

玻璃的物理性能和化學分析如下:

物理性能: 因篇限於設備, 只測定了下列三 項:

\begin{tabular}{|c|c|c|c|}
\hline 數 物 & $\begin{array}{l}\text { 軟化 } \\
\text { 温庋 } \\
\left({ }^{\circ} \mathrm{C}\right)\end{array}$ & 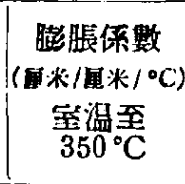 & 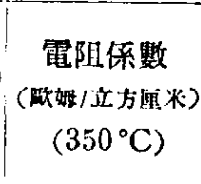 \\
\hline 005 & 740.0 & $40.0 \times 10^{-7}$ & 數㨜后待校正 \\
\hline $008(2)$ & 739.5 & $41.4 \times 10-7$ & 數據分待校正 \\
\hline
\end{tabular}

化學分析:

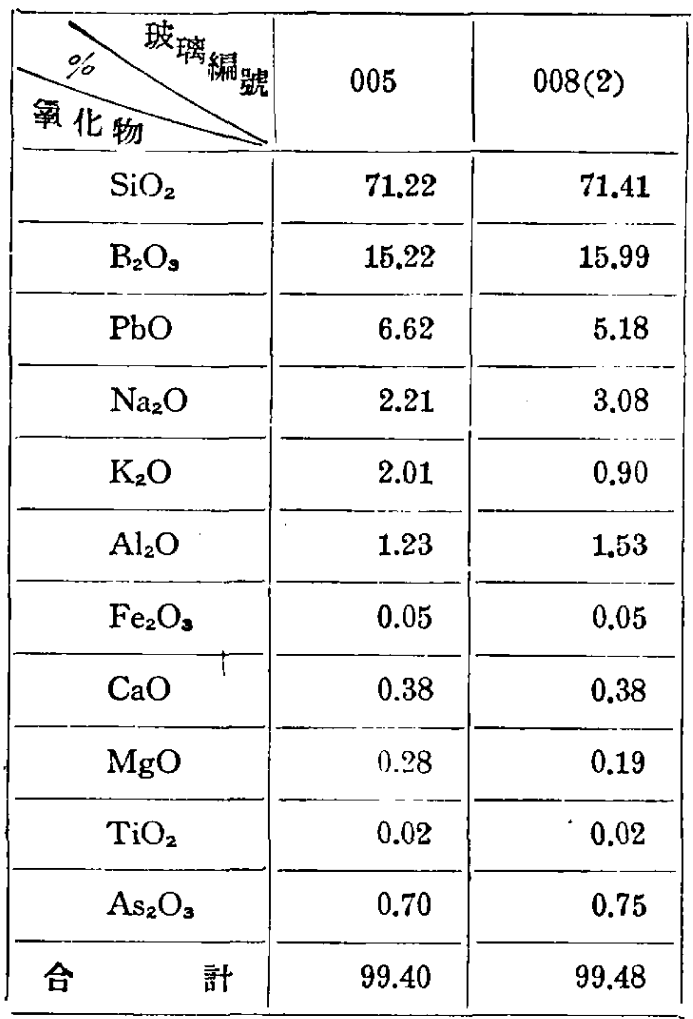

（上列分析是第一械工業部上海 綜 合工 業試驗所代忿分析的)

小型生產試驗結果:

在試驗最後階段, 我們進行了一次成品的小 型生産試驗。用每堝 85-86 公斤粉料(折合玻唡 72-73公厅）的容量, 進行了三次熔製, 試製的 成品是: T-18 B 2 型整流管玻㲄， T-10-LL 型 放垯燈玻款和直徑 3.6 毫米至 30 毫米的各種玻唡 管。這次試驗的結果, 不很理想, 成品率很低, 主 要是由於: 本所玻璃試驗工場的技工同志技街水 本高低不一, 工作配合太美, 模子設計有缺點和 嘘温控制不够理想等等原因。不過通過逼次試 驗, 我們初步肯定, 如果探用上述等造程序, 到 生産條件此我們完備的工嶥去推廣, 成品率一定 還可以提高培多。 
我們㯰次試驗, 垶於员空管玻琌來說, 祇是 散了一次對 G 702 P “Nonex" 玻琌的仿製工作。 算際上適宜做员空管的玻琌並不限於 G702 P “Nonex”一種, 因此，對於员空管玻琌的研究， 這僅僅是一個開始。如果今後能獾得真空管或其 他類型的電子管製浩部門和研究部閒的密切配 合, 在這方面一定遗有許多工作可以做。

此外, 就對於 G 702 P “Nonex” 玻琌來說, 我們也觝做到了在成份上和性能上接近這種玻 琌, 初步可用而巳。因此, 如果要更淮一步篺密
控制全部製造程序, 改淮設備, 使這仿製工作再 提高一步，也還是有許多工作可以做的。

所以，我們希望以造個試驗作䉆一個開端, 在今後與各有關部門密切合作，使员空管玻璃的 製造問題, 逐步得到完滿的解决。

最後, 我們在這次試驗中承前韮東工業部電 氣工業處沈良雕先生、南京電工版以及交通大學 電子管研究委員會多方協助, 使我們在工作上得 到許多便利, 特此誌謝。

\section{荔枝開花結果問題的研究 \\ 疗 文訓 \\ （踾建量警院）}

荔枝年年開花很多, 但結果很少, 有時甚至 没有收嚄, 逜是生産上的大問題。我自 1950 年 開始觀察苏枝開花的替性，1953年繼續観察的結 果, 認雼結果少的問題是可以解决的。現把 1953 作的一次觀察結果報告如下:

（一）荔枝開花替性和結果的關係: 荔枝有 绕種不同的開花習性, 有少數的崔花先開, 最後 一期開婎花; 有少數的雄花自始至終開放; 但大 體說來都是雄花先開, 倠花後開。由開雄花轉換 到開比花的時候, 中間有上段明顯的休息時間, 其時間長短, 開花多少, 受温度影響很大。根據 我對 “元紬”（福州裁境最普遍的品種）12 個花 穂的觀察, 都是在雄花第一期開後, 過了 $2 、 3$ 天再轉開崔花, 在雌花最初開放的 4、5 天內, 经株没有一桑雄花開放。在同品種其他的十多株 中, 由開雄花轉到開倠花的時間, 掘早上踓然不 同, 但習性都是一樣。昆花雖然有雄芯芯, 但這種

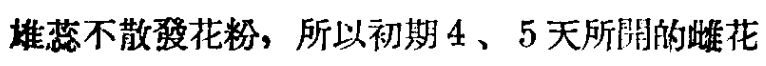
固然很多, 但因當時沒有雄花開放, 不能授粉。 4、5 天以後予有雄花興呲花混開, 但這時崔花 已近結束的時期, 能够得到花粉而受精結果的極 少, 且柱頭開叉, 能接受花粉的時間很短, 倘在 最後短短的 $3 、 4$ 天中, 天氣寒冷或下雨, 妨礙 傳粉媒介的活動, 迶些踓花就無法接受花粉, 也
就不能結貫。這次觀察的 12 個花穗最高的結 果 率是 $10.8 \%$, 最低的 $1.5 \%$, 平均 $4.28 \%$ 。

如果在唯花盛開的時候, 附近有其他品種正 在盛開雄花, 這時天氣好, 氣温高, 缹度低, 像 粉媒介很活動, 那末結果率可以菂加。渞次觀察 10 株, 每株 10 個花悡, 早開花的品種, 在唯花盛 開時, 恰當迟開花的品種開第一期雄花, 由於授 粉比較充分, 結果率有顯渚的增加。检查 50 穗中, 最多的一穗結 22 粒果實, 平均每穗 13 粒, 此晚 開花的多 9 倍。

由上所述, 可以認鳻荔故的開花多而結果少 的原因, 是由於踓雄花開放時期不同, 倠花上的 雄荵退化, 杜頍有受粉能力的時間很短。因此, 絕大部分的此花未能受粉。如能配置開花時期不 同的品種, 在適宜的氣候條件下, 使嶉花得到古 份的花粉, 是能提高苏枝的結果率的。

(三) 荔枝小核和授粉的阔係：根據二年來 的觀察，大核品種都比小核結果多。我既注意小 核荔枝是否要經過投粉的問題, 這次選摆 2 株, 每株選 4 䅹淮行觀察。在 1953 年 4 月 29 日崔花 開放前…天，用透明玻淿紙袋套上，始終不與体 粉媒介相接觬，5月21日去袋檢查, 没有一染雌

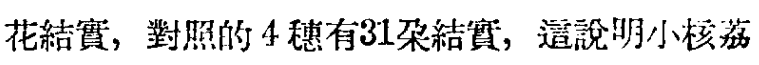
枝, 也必須經過授粉的刺激, 果實始能發育長大。 